\title{
Serological response to pandemic influenza A/H1N1 2009 and seasonal influenza A/H3N2 among health care workers (HCWs) in JIPMER, Puducherry
}

\author{
G Nandhini, S Sujatha*
}

\begin{abstract}
From 2nd International Science Symposium on HIV and Infectious Diseases (HIV SCIENCE 2014)
Chennai, India. 30 January - 1 February 2014
\end{abstract}

\section{Background}

Serum antibody titers against influenza viruses are regarded as markers of partial or complete immunoprotection. Antibody titer of $\geq 40$ is associated with at least a $50 \%$ reduction in risk for infection or disease.

\section{Methods}

Serum was collected from $138 \mathrm{HCWs}$ including laboratory personnel, doctors and nurses working at JIPMER, Puducherry during August - October 2013. Details of influenza vaccination and laboratory confirmed influenza infection were noted. Hemagglutination inhibition assay was performed to determine the serum antibody levels against WHO reference antigens - pandemic influenza A (H1N1) A/California/07/2009, seasonal influenza A (H3N2) A/Victoria/361/2011.

\section{Results}

Fifty of the HCWs had received pandemic influenza vaccination at least once in the previous three years. All HCWs had antibody titers $\geq 40$ against seasonal influenza A/H3N2. Antibody titers against pandemic influenza A/H1N1 2009 ranged from $\leq 20(16.7 \%)$ to 320 with $36.9 \%$ showing borderline protective titers $(=40)$. Six of the vaccinated HCWs had non-protective antibody titers while 71 unvaccinated HCWs showed protective titers. Only one $\mathrm{HCW}$ developed seasonal influenza A/H3N2 infection despite having borderline protective antibody titer of 40 and his convalescent serum sample after two weeks showed fourfold rise in titers.

\footnotetext{
* Correspondence: sujathasistla@gmail.com Department of Microbiology, JPMER, Puducherry, India

\section{Conclusion}

This study showed protective antibody levels against pandemic influenza A/H1N1 2009 and seasonal influenza A/H3N2 among a large percentage of HCWs, regardless of vaccination status, which may be the primary reason for the low incidence of influenza cases encountered this year.

Published: 27 May 2014

\section{doi:10.1186/1471-2334-14-S3-P41}

Cite this article as: Nandhini and Sujatha: Serological response to pandemic influenza A/H1N1 2009 and seasonal influenza A/H3N2 among health care workers (HCWs) in JIPMER, Puducherry. BMC Infectious Diseases 2014 14(Suppl 3):P41.
Submit your next manuscript to BioMed Central and take full advantage of:

- Convenient online submission

- Thorough peer review

- No space constraints or color figure charges

- Immediate publication on acceptance

- Inclusion in PubMed, CAS, Scopus and Google Scholar

- Research which is freely available for redistribution

Submit your manuscript at www.biomedcentral.com/submit
() Biomed Central 